\title{
Prof. Nuno Grande
}

Mário Moura*

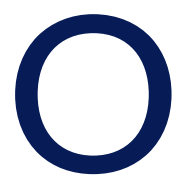

Professor Nuno Grande deixou-nos! Perdeu-se um médico insigne, um professor empenhado, um cidadão completo no seu permanente exercício de cidadania.

A Medicina Geral e Familiar portuguesa deve muito ao Prof. Nuno Grande. Podemos dizer que os Cuidados de Saúde Primários (CSP) começaram em Portugal, na província de Trás-os-Montes, pela intuição e pela força do querer de Nuno Grande. Foi com o seu esforço que, ao abrigo de um programa de apoio e intercâmbio (Norad), a Noruega e a Suécia difundiram, construíram e apoiaram os primeiros centros de saúde com uma concepção polivalente e com funções curativas, preventivas e de relação estreita com as populações.

E foi no Instituto de Ciências Biomédicas Abel Salazar, que Nuno Grande ajudou a fundar, que se criaram os primeiros programas de ensino médico baseados nos CSP, muito antes das outras faculdades de Medicina das nossas universidades clássicas.

Também por sua inspiração se começaram a fazer estagiar alunos de Medicina nos centros rurais, num contacto íntimo com as populações e com os seus problemas intrínsecos, integrando assim o ensino médico nos ambientes envolventes dos pacientes.

Essas práticas, juntamente com uma permanente acção da então Associação Portuguesa dos Médicos de Clínica Geral (APMCG), contribuíram bastante para uma creditação dos CSP nos ambientes do ensino médico tradicional das outras universidades.

E mesmo na APMCG se fez sentir o saber e as con-

*Presidente Honorário da APMGF. vicções do Prof. Nuno Grande pois foi o seu primeiro Presidente da Mesa da Assembleia Geral.

A sociedade nortenha teve sempre no Prof. Nuno Grande um interventivo cidadão em múltiplas actividades científicas, culturais e políticas. Nuno Grande era a imagem e um exemplo a seguir de um cidadão (e de um cidadão-médico) bem integrado e preocupado com o exercício duma cidadania activa. Com as suas permanentes preocupações sociais e os seus conceitos holísticos, foi compreensível, por exemplo, ter aceitado ser Mandatário Nacional da candidatura à Presidência da República da Enga. Maria de Lurdes Pintasilgo. A primeira mulher portuguesa a candidatar-se a tal lugar cimeiro era cristã de formação e prática e defendia um tipo de democracia que valorizava a participação dos cidadãos muito para além de cada período eleitoral, e isto enquadrava-se bem no espírito participativo do Prof. Nuno Grande.

Perdeu-se a presença actuante de um grande médico, de um insigne professor e de um empenhado cidadão, perdeu-se a presença física que não o rastro da sua vida cívica, os efeitos da sua acção como pedagogo e como médico. Estamos certos que se manterá bem viva a sua força e o seu dinamismo nas recordações de todos os que com ele conviveram e muito em especial daqueles que foram seus discípulos. E com muito mais força ficará presente em todos os familiares e amigos que com ele partilharam as suas iniciativas e os vários incidentes da sua vida.

Deixou-nos um Homem com um H grande!

ENDEREÇO PARA CORRESPONDÊNCIA

mario-moura@netcabo.pt 